\title{
RECIDIVANT NEUROBORRELIOSIS: CASE REPORT
}

\author{
Merdin S. Markisic ${ }^{1}$, Mirsad S. Markisic ${ }^{1}$, Sabina B. Markisic ${ }^{2}$, Dragan M. Pavlovic ${ }^{3}$ \\ ${ }^{1}$ General Hospital Berane, Montenegro \\ ${ }^{2}$ Health Center Plav, Montenegro \\ ${ }^{3}$ Faculty for special education and rehabilitation, University of Belgrade, Belgrade, Serbia
}

\author{
RECIDIVANTNA NEUROBORELIOZA: \\ PRIKAZ SLUČAJA

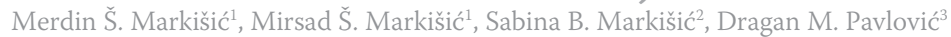 \\ ${ }^{1}$ Opšta Bolnica Berane, Crna Gora \\ ${ }^{2}$ Dom Zdravlja Plav, Crna Gora \\ ${ }^{3}$ Fakultet za specijalnu edukaciju i rehabilitaciju Univerziteta u Beogradu, Beograd, Srbija
}

\begin{abstract}
We present a case of a young woman, age 34, who presented with recurrent Lyme neuroborreliosis (LNB). Her clinical profile consisted of a rare combination of two thirdstage manifestations, namely, progressive encephalomyelitis and peripheral neuritis, in both bouts of the disease. The epidemiological data were controversial, as she reported a tick bite only two months prior to the onset of symptoms. Negative magnetic resonance imaging (MRI) results excluded multiple sclerosis, vascular causes and tumours. Serological tests confirmed the $\mathrm{Bb}$ infection in the recommended twostep serological approach consisting of an enzyme-linked immunosorbent assay (ELISA) test for Borrelia burgdorferi (Bb) immunoglobulin $G(\operatorname{IgG})$ and immunoglobulin $M$ (IgM) and a Western blot (WB) as confirmatory analysis in the blood. Another controversial issue is the lack of pleocytosis. Atypical findings in our patient can be explained by a possible rare genotype of Bb. After treatment with oral doxycycline, she made an apparent remission, but after three months, she had another episode with signs of central and peripheral nervous system involvement, increased $B b$ antibodies and white matter changes on the MRI. This time, she was treated with intravenous ceftriaxone, 2 grams daily for four weeks. She showed no signs of LNB, both clinically and serologically, during a follow up lasting about a year. This case emphasises the importance of the clinical and serological findings and the use of ceftriaxone as the first line of treatment in LNB.

Key words: Lyme neuroborreliosis, progressive encephalomyelitis, neuritis, ceftriaxone
\end{abstract}

\section{SAŽETAK}

Mi predstavljamo slučaj mlade žene starosti 34 godine sa rekurentnom Lajmskom neuroboreliozom (LNB). Njena klinička slika se sastojala od retke kombinacije dve manifestacije treće faze, naime, progresivnog encefalomijelitisa i perifernog neuritisa u obe epizode bolesti. Epidemiološki podaci su kontroverzni jer se ubod krpelja desio samo dva meseca ranije. Magnetna rezonanca (MR) mozga je isključila multiplu sklerozu, vaskularne uzroke i tumor. Serološki testovi su potvrdili Bb infekcije u preporučenoj serologiji u dva koraka, sa enzyme-linked immunosorbent assay (ELISA) testom za Borrelia burgdorferi (Bb) specifične imunoglobuline $G(I g G)$ i imunoglobulina M (IgM) $i$ Vestern Blot (VB) testom za konfirmaciju. Drugo kontroverzno pitanje je nedostatak pleocitoze u likvoru. Atipični nalazi u naše bolesnice mogu se objasniti retkim genotipom Bb. Nakon tretmana sa oralnim doksiciklinom, bolesnica je postigla remisiju, ali je posle tri meseca imala još jednu epizodu sa znacima zahvaćenosti centralnog $i$ perifernog nervnog sistema, povećanim titrom specifičnih Bb antitela kao $i$ promenama bele mase na MR mozga. Ovaj put, ona je tretirana ceftriaksonom intravenski, dva grama dnevno tokom četiri nedelje. Bolesnica je ponovo ušla u remisiju LNB koja se održavala $i$ klinički i serološki tokom praćenja u trajanju od oko godinu dana. Ovaj slučaj naglašava značaj kliničkih i seroloških nalaza u dijagnostici kao i opravdanost ceftriaksona, kao prve linije lečenja u LNB.

Ključne reči: Lajmska neuroborelioza, progresivni encefalomijelitis, neuritis, ceftriakson 


\section{INTRODUCTION}

Lyme neuroborreliosis (LNB) is a disease of the central nervous system (CNS) and/or peripheral nervous system (PNS) caused by the spirochete Borrelia burgdorferi (Bb) as part of a general infection referred to as Lyme borreliosis (LB) or Lyme disease $(1,2)$. In Europe, LNB is caused by Bb sensu lato-mainly Borrelia garinii and Borrelia afzeliiand rarely $\mathrm{Bb}$ sensu stricto, whereas in North America, the only bacterium is Bb sensu stricto $(3,4)$.

LB clinically manifests in the following three stages: first or early localised disease, second or early disseminated disease and the third or late disseminated disease $(1,5)$. Lyme neuroborreliosis upcomprises $10-15 \%$ of all cases of LB.

\section{The first stage}

In the first stage of LB, the typical skin manifestation is Erythema migrans (EM), a red circle at least $5 \mathrm{~cm}$ in diameter. As this circle enlarges, its centre becomes pale. Neurological disorders are less common in the early stages and may manifest by headache, muscle pain and fever, with or without EM (6). The titre of antibodies in the blood at this stage is negative, and the diagnosis is based solely on the identification of the clinical and epidemiological data regarding the tick bite.

\section{The second stage}

In the second stage of LB, there are neurological, rheumatological, cardiac and skin manifestations (4). The most typical manifestations of the second stage of LNB are as follows: painful meningoradiculitis or Garin-BujadouxBannwarth syndrome (GBBS), meningitis, encephalitis, cranial mono- and polyneuritis, and myelitis. Less common symptoms includelythere is plexitis, myositis, pseudotumour of the brain, vasculitis, ataxia and other clinical manifestations (7).

Painful meningoradiculitis occurs within the first four months after the tick bite (4). The position of pain in the body changeschanges and arm and leg weakness can occur, as well as neck stiffness. Cerebrospinal fluid (CSF) pleocytosis is characteristic with hyperproteinorachia and sometimes a positive oligoclonal response.

\section{The third stage}

The third stage of LB consists of neurological, rheumatological and dermatological manifestations. The third stage may occur without any apparent manifestations of the first two stages, and in many cases, patients do not recall a tick bite. In the third stage, the most prominent clinical entities are progressive encephalomyelitis, encephalopathy, neuropathy (with or without acrodermatitis chronica atrophicans), dementia, myositis, granulomatous CNS tumour and vasculitis (4).

Progressive encephalomyelitis is characterised by spastic paresis, ataxia, cranial nerve damage (ofnamely, cranial nerves VII and VIII), micturition disturbances and other signs (8). The CSF signs are pleocytosis, hyperproteinora- chia, oligoclonal response and intrathecal synthesis of the IgG and IgM immunoglobulins es(9). In the case of CNS involvement, it is beneficial to perform magnetic resonance imaging (MRI) of the brain and possibly the spinal cord (10). It is possible for cranial neuropathy and meningitis to appear on the MRI due to the enhancement after contrast application.

Encephalopathy of LNB is expressed byas fatigue, memory disturbances, headache, confused state, depression, daytime sleepiness, irritability and dysnomia (4). ,Additionally, there are various neuropsychological deficits (11). An MRI can reveal small white matter lesions of the brain. Specific antibodies to $\mathrm{Bb}$ in the CNS are found in $50 \%$ of these cases.

In neuropathy, muscle stretch reflexes are reduced or absent and there is weakness and numbness of the limbs, pain and muscle cramps.

\section{Diagnosis of Lyme neuroborreliosis}

Microbiological methods of diagnosis, which can prove LB , can be direct and indirect $(12,13)$. Direct diagnostic methods include culturing pathogens in appropriate substrates and detection of genetic material (14). Indirect methods can confirm infection by the detection of specific antibodies $(15,16)$.

Borrelia cultivation is the best and the only accurate evidence of an infection with $\mathrm{Bb}$, especially when $\mathrm{Bb}$ is in atypical clinical forms and for patients who do not develop a proper specific immune response. However, the cultivation of $\mathrm{Bb}$ sensu lato is a very complex and time-consuming method (9 weeks and even longer) and can be performed only in well-equipped laboratories $(12,17)$.

It is necessary in the case of suspected LB, based on symptoms, to start a serology examination with an enzyme-linked immunosorbent assay (ELISA) test for $\mathrm{Bb}$ immunoglobulin G (IgG) and immunoglobulin M (IgM) (4). Determination of rheumatoid factor (RF) and Venereal Disease Research Laboratory (VDRL) in the blood is mandatory to exclude the most common false-positive results: rheumatoid arthritis and syphilis. It is also necessary that the ELISA be positive in at least two different samples. If the ELISA is positive, a confirmation test is required (because of the possibility of false positive results) with Western blot (WB) analysis, which demonstrates the specificity of previous findings (9). Falsepositive and/or misinterpreted laboratory findings are often the cause of patients wandering from one doctor to another doctor and not having adequate support. It is suggested that all serological tests are performed using both the serum and the CSF (9).

The new European criteria for LNB includes two levels of LNB diagnosis: definite and possible LNB (18). A definite LNB must include at least two of the following three criteria: 1. neurological symptoms; 2. CSF pleocytosis; and/or 3. intrathecal synthesis of antibodies to Bb. Antibodies may be negative in the first 6 weeks. It is always necessary to exclude other causes of current symptoms, 
as diagnostic errors are common. I gM has no diagnostic value in late LNB, and if it is an isolated finding, it is usually indicative of a false positive and is thus likely caused by some other disease (19). IgM class antibodies appear by the third week and IgG antibodies from the sixth week after the infected tick bite.

IgG antibodies to $\mathrm{Bb}$ usually remain positive throughout the patient's life, even after successful treatment of Lyme disease (20). IgG and IgM antibodies can persist in the CSF long after receiving adequate therapy and showing no further evidence of active neurologic disease.

\section{Treatment of Lyme disease and \\ Lyme neuroborreliosis}

Antibiotic therapy is causal treatment for LB and LNB (21). It is necessary to perform the correct diagnostic procedure before treatment to prevent the application of a long-term therapy that is inadequate for a disease other than LNB. Such a misstep can lead to unnecessary complications.

In the earlier stages of LB, the efficacy of oral doxycycline 100 milligrams every 12 hours daily for 14 days was shown to be effective. The drug of choice for the third stage of the LNB is ceftriaxone, which is given intravenously 2 grams a day for three to four weeks (21). Improvement in acute cases occurs in a few days and in chronic cases after several months or even longer ( 8 months or more). An improvement or cure is found in $90 \%$ of cases. Alternatively, intravenous cefotaxime or penicillin or amoxicillin orally is given. If there is possible LNB, one course of antibiotic therapy is sufficient, and if there is no improvement, one should look for other causes. If the criteria have been met for definite LNB and the therapy was ineffective after more than six months, the condition is called post Lyme syndrome (22). In this syndrome, antibiotic therapy is not effective. In children younger than 9 years of age, doxycycline is contraindicated.

\section{A CASE REPORT}

Our patient was a 34-year-old woman who was admitted to the neurology department of the General Hospital Berane on two separate occasions, in April and July of 2008, suffering from fatigue, headaches, weakness in the arms and legs, difficulty walking, ataxia, numbness of the face and neck stiffness. Anamnestic data stated a tick bite two months before her first admission.

During her first hospitalisation in April, the patient complained of malaise, headaches, weakness in the arms and legs (difficulty in walking, ataxia), numbness of the face and neck stiffness. Neurological examination on admission showed she had hypesthesia of the left half of the face. Her neck was slightly stiff, but she tested negative for meningeal signs. She had weakness in both arms, as well as in both legs. Her muscle stretch reflexes were increased in all four extremities, and her extended reflex zone was found with patellar and feet clonus on both sides. Her plantar reflex was absent.

On the basis of the clinical presentation disseminated, the CNS disease was supposed and the necessary diagnostic procedures were performed. Magnetic resonance imaging of the brain and cervical spine were performed in April, and the findings were normal. The ELISA results for IgG and IgM antibodies to Bb in serum were positive and confirmed by WB. The serodiagnosis was confirmed positive on several occasions. Control serologic tests in May were positive, whereas in June, the findings were normal. The cytological findings in the CSF were within normal limits. Isoelectric focusing of CSF showed normal results. Electromyoneurography (EMNG) of the upper and lower extremities indicated predominantly axonal neuropathy, which is aetiologically associated with the underlying disease, i.e., LNB. Routine laboratory tests showed normal results.

During her first hospitalisation in April, after receiving positive serological findings for $\mathrm{Bb}$, the patient received doxycycline tablets at a dose of $100 \mathrm{mg}$ per 12 hours for one month, after which there was an improvement and a reduction of symptoms in May.

A recurrence of symptoms occurred in July of the same year when she was readmitted to the hospital. A neurological examination revealed the following findings: her cranial nerve findings were normal, her meningeal signs were negative, she had a slightly stiff neck, both her arms and legs were weak predominantly on the left side; her muscle stretch reflexes were increased bilaterally and had enhanced reflexogenic zone and she had patellar and feet clonus present on both sides with a normal plantar reflex.

All routine laboratory tests were within normal range. Her brain MRI results revealed the presence of changes in the deep paraventricular white matter which corresponded to changes observed in LNB. AnHer ELISA test showed a rise in $\mathrm{Bb}$ antibody titre of IgG and IgM in serum. ,Additionally, a confirmatory WB test in July showed the she had increased titres of specific antibodies. New CSF cytological and biochemical findings and isoelectric focusing of CSF again showed normal findings. The EMNG finding was unchanged compared to the previous test.

Given that LNB reoccurred despite previous treatment with doxycycline, therapy with ceftriaxone at a dose of one gram per 12 hours as an intravenous infusion during four weeks was administered in July. An improvement in symptoms occurred after a few days, and the neurological status upon discharge fromafter the second hospitalisation showed only increased muscle stretch reflex on the left leg.

In August, after one month, follow up controls were performed, and then in September, October and November of the same year with normal neurological findings. In August and November of 2008 and March of 2009, the serological results were negative. Based on clinical and serological criteria, there was a complete remission of the disease. 


\section{DISCUSSION}

We presented a case of a female patient with LNB, which fulfilled the criteria for the third stage of LNB, with progressive encephalomyelitis and neuropathy (4, 21). AThe short time interval between the occurrence the tick bite and the presentation theof the symptoms and the dynamics of serology are arguments against a causal relationship, so these occurrence of these issues was most likely a coincidence. Therefore, the infection was most likely acquired during an earlier infected tick bite that had not been registered.

The visibility of ticks on the skin depends on the tick's size and itsthe duration of its stay on the host's skin (4). Young forms, such as larvae, often go unnoticed because they are less than $1 \mathrm{~mm}$ in diameter and can release themselves or be accidentally removed before they are noticed. However, the larvae are also less contaminated. Nymphs, the intermediate developmental stage of ticks, are the most typical carriers of infection. Nymphs have a higher percentage of infection with $\mathrm{Bb}$, and even thoughtthough they are larger than larvae, are small enough to be less detectable and can stay on the skin of the host long enough (more than 24 hours) to transfer the infection. Adult ticks are larger (a few millimetres in diameter) after ira blood meal and can be observed easily and removed quickly; therefore, they usually do not have enough time to transfer $\mathrm{Bb}$ to the host. After infection with Bb, EM may be lacking in half of patients with LB (23), as was the case for our patient.

Pertaining to LNB, in almost half of the cases, the data on the tick bite and/or EM are missing (9). This gap in the available data makes the diagnosis of LNB difficult, but even the information about the tick bite, as was the case in our patient, can be misleading. It is considered that for the development of the third stage of LNB to occur, at least 6 months have tomust pass, which in our case was not fulfilled, thus indicating an earlier infection. Also, the tick bite, which occurred two months before the onset of symptoms, was not accompanied by the appearance of EM or other manifestations of the first stage of LB. There were no data on the manifestation of the second stage in our patient. Many patients with third stage LNB not only lack epidemiological data about the tick bite, but also lack information about the first/second stage clinical manifestations (4). In such cases, there is a particular need for a good deferential diagnosis that encompasses multiple sclerosis, small vessels disease of the brain, neuropathy, and various other neurological, rheumatological and even psychiatric diseases (20).

An interesting point of our case is the simultaneous existence of two manifestations of late LNB - namely, progressive encephalomyelitis and neuropathy-and no signs of skin manifestations of acrodermatitis chronica atrophicans. An immediate response of neuropathy to ceftriaxone is also intriguing, as usually one has to wait several months for a response to occur (21). The emergence of resistance to therapeutic antibiotics or recurrence of clinically expressed infection may be explained by multiple mechanisms. Doxycycline is usually ineffective during the later stages of the disease, but dissemination leads to improvement, or there is a "decapitation" of infection, but it is not eradicated and consequently reappears. Less frequently, there might be a new infection, but then the time period between the two episodes of the disease necessarily has to be longer.

The value of ELISA IgG and IgM tests in the first steps of serological diagnosis has been confirmed. Positive findings are followed up by WB analysis, which serves as a confirmatory test because of its higher specificity (22). Typically, there is an increase in specific IgM antibodies in the beginning of the infection, and then the subsequent appearance of IgG antibodies, followed by the disappearance of $\operatorname{IgM}$ and the persistence of IgG antibodies as a type of "immunological scar" (4). The persistence of IgM antibodies is rare but possible. Increased persistence of only IgM positivity is a false positive finding (19). The diagnosis of LB is primarily based on clinical findings, and serological results should be used only to confirm the diagnosis (24).

One of the controversies surrounding LNB involves CSF inflammatory syndrome. Inflammatory syndrome in CSF is commonly present in patients with meningitis and/or encephalitis in LNB. Although some authors consider inflammatory syndrome in CSF mandatory for the diagnosis of LNB, the experience of other authors shows that it is not always present (25). A positive inflammatory response of pleocytosis and hyperproteinorachia supports the diagnosis of neuroinfection along with other data-in particular, the presence of specific $\mathrm{Bb}$ antibodies, data on the tick bite and the corresponding clinical manifestations. The disappearance of inflammatory syndrome follows therapy. European criteria include pleocytosis while the U.S. criteria does not include pleocytosis (25). While inpleocytosis is usually present in European LNB, the absence of pleocytosis can be explained by early stage disease, immunosuppression, infection with $\mathrm{Bb}$ sensu stricto, or the presence of atypical genotypes. In addition, some of our previous patients who fulfilled all of the other criteria for LNB and underwent successful antibiotic therapy did not have pleocytosis, so we propose the presentation of different microbiological characteristics of $\mathrm{Bb}$ genotypes in our region $(26,27)$.

Polyneuropathy in LNB is rarely not accompanied with acrodermatitis chronica atrophicans (ACA) and usually has normal CSF findings. Polyneuropathy without ACA has been reported previously, but it occurs much more frequently in North America than in Europe. (28). This feature was also a distinctive symptom of our patient and is another argument in favour of the involvement of a less frequent $\mathrm{Bb}$ genotype.

In some patients with involvement of the brain, nonspecific white matter changes on MRI are found (10). In the diagnosis of LNB, MRI plays more of a role in excluding other causes than providing direct proof of the disease $(10,29)$, as was the case for our patient. 
Ceftriaxone is the drug of choice for later stages of LB, especially the third stage of LNB (18). Although the published literature recommends courses of two to four weeks of intravenous cephtriaxone, in our experience, it is more efficient and safer to give 2 grams per day for longer courses of three to four weeks, so that the infection may be eradicated. AHowever, there are different opinions on this possibility, as there may be asymptomatic chronic persistence of $\mathrm{Bb}$ even after therapy $(19,21)$.

Long courses of oral antibiotics, either alone or after parenteral therapy, are controversial, and there is not enough evidence to support its increased efficacy (18). Giving ceftriaxone, an antibiotic proven to be effective for the treatment of $\mathrm{Bb}$, parenterally at a dose of 2 grams a day for three to four weeks, fulfils the old clinical maxim: give the appropriate drug, in the appropriate dose, long enough. After such treatment, infection recurrences are significantly lower, as was the case for our patient. Symptoms of successfully treated LNB can persist for up to 8 months and, in the case of neuropathy, even for as long as two years (4). It is interesting that in our patient, a longer course of ceftriaxone led to the prompt withdrawal of both forms of late LNB, which co-existed. LNB can be successfully treated with adequate antibiotics (22).

It should be emphasised that there is a logistical problem of diagnosing LNB in smaller towns in which the availability of additional diagnostic methods is significantly lower than in the large centres. Clinical diagnosis of neurological diseases is critical and requires vigilance on several levels: a high level of suspicion for LNB and a detailed disease history, as well as a detailed and accurate neurological examination. Medical histories should particularly address the epidemiological information about the tick bite, the presence of EM or other more specific manifestations of LB or LNB in earlier stages, as in the case of patients such as ours, suffering from the third stage of LNB. The absence of data on the tick bite does not exclude diagnosis of LNB, so in such cases, one should insist on learning if there were possible trips to the countryside with greenery and travel to endemic areas where tick habitats exist (30). Serodiagnostics of LB takes two steps (9). The first step is an ELISA test for Bb specific IgG and IgM antibodies in serum (preferably also in the CSL), and in the case of positive findings, a WB to detect IgG and IgM in serum (preferably in the CSL) can be performed to confirm the diagnosis. In the early stages, serological findings are negative and antibodies appear after about a month or two of repeated testing (4). Neurologists in smaller towns should establish cooperation in advance with one of the reference laboratories dealing with such diseases. Proving pleocytosis in CSF is controversial, as already discussed, and the presence of an increased number of lymphocytes supports LNB along with other positive findings, but the absence of pleocytosis does not make a case against LNB. Further diagnostic processing in the case of CNS involvement should consist of brain and/or spinal cord MRI and, in the case of PNS, the involvement of EMNG performed on all four limbs. Other specific diagnostic procedures are not standard, even in the major centres of LNB, because of their lack of sensitivity and specificity (polymerase chain reaction - PCR, Bb isolation, etc.). PCR for clinical samples has demonstrated a low sensitivity for the diagnosis of LB using blood and CSF (29).

In our patient, this order was respected and LNB was proven, as well as its recurrence. LNB therapy is often a complex process and requires an assessment of the whole set of circumstances (possible neurological and/or other comorbidities, allergies to antibiotics, immune status, etc.) (23).

Given the relative resistance of pathogen, we suggest as a reliable solution, therapy with ceftriaxone, two grams per day of intravenous infusion, preferably divided in two daily doses, for three to four weeks, less in second, more in the third stage. This therapy proved to be successful in our patient (Pavlović, 2012; Bhate, Schwartz, 2011) (21, 22). We emphasise a rare coincidence of two events of the third stage of LNB, namely, progressive encephalomyelitis and peripheral neuritis in our patient, which complicates treatment.

\section{CONCLUSION}

Lyme disease manifests itself through a whole range of different clinical manifestations, especially in the skin, nervous system, heart and joints, and is divided into three stages. Our patient was a young woman in her thirties who presented with the third stage of LNB. She presented with a clinical picture of progressive encephalomyelitis and peripheral neuritis, which is a rarity. Serological tests are important in the diagnosis of LB but only along the clinical findings, and these tests are not, by themselves, the determining factor in establishing the aetiological diagnosis. An effort should be made in the case of suspected LNB cases to simultaneously examine CSL and serum for specific $\mathrm{Bb}$ antibodies. A positive ELISA test in the first step requires confirmation with a WB test. Additional testing includes MRI and/or EMNG. LNB treatment with intravenous ceftriaxone or oral doxycycline depends on the stage of the disease. Due to the potential for less sensitivity of $\mathrm{Bb}$, it is advisable to use ceftriaxone as antibiotic of first choice in all cases of proven LNB, as was confirmed in our patient.

\section{REFERENCES}

1. Dulović O. Aktuelni aspekti lajmske bolesti. Acta Infectol Yugoslav 2002;7:7-10.

2. Pavlović DM. Klinički oblici Lajmske neuroborelioze. Seminar: Lajmska bolest i krpelji. Skupština grada Beograda i Gradski zavod za zaštitu zdravlja Beograda. Beograd 2003:20-21.

3. Djukic M, Schmidt-Samoa C, Nau R, von Steinbüchel $\mathrm{N}$, Eiffert $\mathrm{H}, \mathrm{Schmidt} H$. The diagnostic spectrum in patients with suspected chronic Lyme neuroborrelio- 
sis--the experience from one year of a university hospital's Lyme neuroborreliosis outpatients clinic. Eur Neurol 2011;18(4):547-55.

4. Pavlović D, Dmitrović R. Lajmska neuroborelioza. Beograd: Elit Medica 1996.

5. Bojić I. Evropska borelioza (Lajmska bolest), Loznica: Naš dom; 2000.

6. Pavlović D. Glavobolja kod Lajmske neuroborelioze. Medicinska Istraživanja 1996;29:33-34.

7. Pavlović D, Milović A, Dmitrović R. Kranijalni polineuritis u Lajmskoj neuroboreliozi. Materia Medica 1999;15:38-40.

8. Павловић А, Аевић 3, Амитровић Р, Оцић Г. Хронични енцефаломијелитис изазван борелијом бургдорфери. У: АкаА Петровић 3. (уреА.). Аајмска борелиоза. Глас 370 Српске академије наука и уметности, одељење меАицинских наука, књ. 43, БеограА 1993:225-28.

9. Pavlović DM, Pavlović AM. Lajmska neuroborelioza patogeneza i dijagnostika - novi aspekti. Acta Infectologica Yugoslavica 2000;5:147-151.

10. Agarwal R, Sze G. Radiology 2009;253(1):167-73. Neuro-lyme disease: MR imaging findings.

11. Eikeland R, Ljøstad U, Mygland A, Herlofson K, Løhaugen GC. European neuroborreliosis: neuropsychological findings 30 months post-treatment. Eur J Neurol 2012;19(3):480-7.

12. Strle F, Nelson JA, Ružić A, Picken RN. European Lyme borreliosis: 231 culture-confirmed cases involving patient with erythema migrans. Clin Infect Dis 2002;23:61-5.

13. Preac-Mursic V, Wilske B. European Borrelia burgdorferi isolated from humans and ticks. Culture conditions and antibiotic susceptibility. Zentralbl Bakterol Mikrobiol Hyg A 1999;263:112-8.

14. Tilton RC, Rayan RW. The laboratory diagnosis of Lyme disease. J Clin Immunoassay 2003;16:208-14.

15. Goossens HAT, Nohlmans MKA. Evaluation of fifteen comercially available serological test for diagnosis of Lyme borreliosis. Eur J Clin Microbiol Infect Dis 1999;18:551-60.

16. Dressler F. The cell proliferation assay in the diagnosis of Lyme disease. Ann Intern Med 2001;115:533-46.

17. Huppertz HI, Standeart SM, Plotkin SA. Incidence of Lyme borreliosis in the Wurzburg Region of Germany. Eur J Clin Microbiol Infect Dis 1999;18:697-703.
18. Mygland A, Ljøstad U, Fingerle V, Rupprecht T, Schmutzhard E, Steiner I. EFNS guidelines on the diagnosis and management of European Lyme neuroborreliosis. Eur J Neurol 2010;17(1):8-16, e1-4.

19. British Infection Association. The epidemiology, prevention, investigation and treatment of Lyme borreliosis in United Kingdom patients: a position statement by the British Infection Association. J Infect 2011;62(5):329-38.

20. Ljøstad U, Mygland $\AA$. The phenomenon of 'chronic Lyme'; an observational study. Eur J Neurol 2012;19(8):1128-35.

21. Pavlović DM. Neuropsihologija, bihevioralna neurologija i neuropsihijatrija. Beograd: Orion Art, 2012.

22. Bhate C, Schwartz RA. Lyme disease: Part II. Management and prevention. J Am Acad Dermatol 2011;64(4):639-53.

23. Bhate C, Schwartz RA. Lyme disease: Part I. Advances and perspectives. J Am Acad Dermatol 2011a;64(4):619-36.

24. Gajović O, Todorović Z, Nesić L, Lazić Z. Lyme borreliosis - diagnostic difficulties in interpreting serological results. Med Pregl 2010;63(11-12):839-43.

25. Djukic M, Schmidt-Samoa C, Lange P, Spreer A, Neubieser K, Eiffert H, Nau R, Schmidt H. Cerebrospinal fluid findings in adults with acute Lyme neuroborreliosis. J Neurol 2012;259(4):630-6.

26. Pavlović D, Milović A, Dmitrović R. Lyme neuroborreliosis with normal cerebrospinal fluid findings. VII International Congress on Lyme Borreliosis. San Francisco, June 16-21 1996:137.

27. Strle F, Ruzić-Sabljić E, Cimperman J, Lotrić-Furlan S, Maraspin V. Comparison of findings for patients with Borrelia garinii and Borrelia afzelii isolated from cerebrospinal fluid. Clin Infect Dis 2006;43:704-10.

28. Mygland A, Skarpaas T, Ljøstad U. Chronic polyneuropathy and Lyme disease. Eur J Neurol 2006;13(11):1213-5.

29. Hildenbrand P, Craven DE, Jones R, Nemeskal P. Lyme neuroborreliosis: manifestations of a rapidly emerging zoonosis. AJNR Am J Neuroradiol 2009;30(6):1079-87.

30. Makhani N, Morris SK, Page AV, Brophy J, Lindsay LR, Banwell BL, Richardson SE. A twist on Lyme: the challenge of diagnosing European Lyme neuroborreliosis. J Clin Microbiol 2011;49(1):455-7. 